Sains Malaysiana 50(10)(2021): 3077-3084

http://doi.org/10.17576/jsm-2021-5010-20

\title{
Evaluation of the Relationships between Corneal Parameters, Ocular Biometry, and Myopia Magnitude
}

(Penilaian Hubungan antara Parameter Kornea, Biometri Okular dan Magnitud Miopia)

\author{
Mohd Izzuddin Hairol*, Norlaili Arif, Pui Theng Yong, Mariah Asem Shehadeh Saleh Ali, Nik Nor \\ ADLINA NIK IDRIS \& LI CHING NG
}

\begin{abstract}
Axial length of the eye correlates with the magnitude of myopia. However, there are conflicting reports on the relationship between certain corneal parameters with myopia magnitude. The objective of this study was to compare ocular biometry and corneal parameters between emmetropic and myopic groups. Participants $(n=127)$ were categorized as emmetropia (spherical equivalent, $S E, \pm 0.50 D)$, low myopia $(-0.75 D \leq S E<-6.00 D)$ and high myopia (SE $\geq-6.00 D)$. The difference in axial length, anterior chamber depth, and vitreous chamber depth between emmetrope, low myope, and high myope were highly significant (one-way ANOVA, all $p<0.001$ ) with significant correlations between $S E$ and all these parameters (simple regressions, all $p<0.001$ ). However, central corneal thickness, corneal radius of curvature, and corneal asphericity between these groups, and the correlations between the ocular parameters with SE were not significantly different (all $p>0.05$ ). Corneal curvature correlated significantly with axial length $(p=0.001)$ but not with myopia magnitude ( $p=0.91)$. Rather than myopia magnitude, axial length appears to be more sensitive to detect changes in corneal curvature in myopes. In conclusion, myopic patients' axial length should be carefully considered for interventions that involve the cornea, such as orthokeratology and refractive surgery.
\end{abstract}

Keywords: Axial length; central corneal thickness; corneal parameters; myopia; ocular biometry

\section{ABSTRAK}

Panjang paksi mata berkorelasi dengan magnitud rabun. Walau bagaimanapun, terdapat laporan yang bertentangan mengenai hubungan antara parameter kornea tertentu dengan magnitud. Objektif kajian ini adalah untuk membandingkan parameter biometri okular dan kornea antara kumpulan emmetropik dan rabun. Peserta $(n=127)$ dikategorikan sebagai emmetropia (setara sfera, $S E, \pm 0.50 D)$, miopia rendah $(-0.75 D \leq S E<-6.00 D)$ dan rabun tinggi (SE $\geq-6.00 D)$. Perbezaan panjang paksi, kedalaman ruang anterior dan kedalaman ruang vitreous antara emmetrope, miop rendah dan miop tinggi sangat ketara (ANOVA sehala, semua $p<0.001)$ dengan korelasi yang signifikan antara SE dan semua parameter ini (regresi sederhana, semua p <0.001). Walau bagaimanapun, ketebalan kornea pusat, jari-jari kelengkungan kornea dan aspherisitas kornea antara kumpulan ini dan hubungan antara parameter okular dengan SE tidak jauh berbeza (semua $p>0.05$ ). Kelengkungan kornea berkorelasi dengan panjang paksi $(p=0.001)$ tetapi tidak dengan magnitud ( $p=0.91$ ). Daripada magnitud rabun, panjang paksi nampaknya lebih sensitif untuk mengesan perubahan kelengkungan kornea pada rabun. Kesimpulannya, panjang paksi pesakit rabun harus dipertimbangkan dengan teliti untuk campur tangan yang melibatkan kornea, seperti ortokeratologi dan pembedahan bias.

Kata kunci: Biometri okular; ketebalan kornea pusat; miopia; panjang paksi; parameter kornea

\section{INTRODUCTION}

Myopia is a worldwide visual health problem where those with high myopia are at high risk of developing ocular abnormalities, including retinal detachment and glaucoma (Saw et al. 2005). Correction of myopia has tremendous benefits, including an increase in educational performance and mental health well-being (Guan et al. 2018). It is well documented that in myopia, axial length exceeds the focal length attributed by the refractive components of the eye, thereby influencing the refractive error (e.g. Atchison et al. 2004; Blanco et al. 2008; Lin et al. 1996). As the axial length is the distance between 
the anterior pole to the posterior pole of the eye, it would include the thickness of the cornea, the depth of the anterior chamber, and the crystalline lens's thickness, and the depth of the vitreous chamber. Indeed, myopic eyes have been reported to have a deeper vitreous chamber (Stone \& Flitcroft 2004) and anterior chamber (Dogan et al. 2017) than emmetropic eyes.

There are conflicting reports on corneal parameters' changes with an increase in myopia magnitude by various researchers. Several researchers reported that central corneal thickness does not correlate with myopia magnitude (Al-Mezaine et al. 2009; Dogan et al. 2017; Mostafa et al. 2018), while others reported that it is thicker in high myopia (Wang et al. 2015). These differences could be due to several factors that are known to influence corneal thickness, such as age (Hashmani et al. 2017; Kadhim \& Farhood 2016; Lim et al. 2010), refractive error, corneal curvature, and intraocular pressure (Chen et al. 2009; Cho \& Lam 1999).

There are also conflicting findings regarding the shape of the cornea in myopes. Corneal asphericity coefficient Q represents the curvature of the cornea from its center to the periphery. It also describes the type of conicoid that represents the cornea's shape. It has been reported that as myopia magnitude increases, cornea tends to be more prolate ( $\mathrm{Q}$ becomes more positive) (Zhang et al. 2011) or oblate (Q becomes more negative) (Horner et al. 2000). As with corneal thickness, there are factors that contribute to these differences, including ethnicity (Fuller \& Alperin 2013; Zhang et al. 2011) and measurement methods (Horner et al. 2000; Zhang et al. 2011). For example, African-Americans' eyes are more prolate than those of Whites (Fuller \& Alperin 2013). It has also been reported that Chinese subjects' eyes are prominently prolate (Zhang et al. 2011). Different reported Q results could be due to different measurement methods, where Zhang et al. (2011) derived $Q$ values based on the average eccentricities measured at the central, horizontal, vertical, and four quadrants of the cornea. Whereas, Horner et al. (2000) derived Q from the cornea's central $4.5 \mathrm{~mm}$ diameter.

The differences in corneal parameters described earlier may also be due to how the authors of those studies categorized myopia. The magnitude of myopia is either treated as a continuous parameter (Al-Mezaine et al. 2009; Dogan et al. 2017) or categories (Mostafa et al. 2018; Wang et al. 2015). The International Myopia Institute recently classified myopia into only two categories (low and high), based on the magnitude of myopia (Flitcroft et al. 2019). Categorization is usually done due to practical considerations and ease of interpretation, although it could lead to loss of statistical efficiency (Turner et al. 2010). These different ways to categorize myopia could have led to different conclusions on how corneal thickness and asphericity change with increased myopia magnitude. Such discrepancies would have implications in clinical conditions known to affect the cornea such as keratoconus (Hosseini et al. 2013) or in any interventions involving the cornea such as contact lens wear (Mohidin et al. 2014), cataract surgery (Teoh et al. 2017), and orthokeratology (Liong et al. 2015).

This study's objective was to compare ocular biometry and corneal parameters between emmetropes, low myopes, and high myopes. The study also aimed to compare the correlations between corneal parameters with spherical equivalent and axial length.

\section{MATERIALS AND METHODS}

The study was conducted at the Optometry Clinic, Universiti Kebangsaan Malaysia Kuala Lumpur Campus. All participants were between 21 and 35 years of age. They were categorized according to the spherical equivalent of their refractive error, which were emmetropia $( \pm 0.50 \mathrm{D})$, low myopia $(-0.75 \mathrm{D}$ to $-5.75 \mathrm{D})$, and high myopia $(\geq 6.00 \mathrm{D})$ (Flitcroft et al. 2019). All participants had best-corrected visual acuity of logarithm Minimum Angle of Resolution (logMAR) 0.0 (Snellen 6/6) or better, with astigmatism less than 1.50DC (Mohan et al. 2007). Participants were excluded if they had a history of ocular pathology, systemic diseases, ocular surgery, and medication, wearing any types of contact lenses within 72 hours before data collection, or were pregnant at the time of data collection. The sample size was 127 eyes, which corresponded with an effect size of 0.38 , significance level $\alpha$ of 0.05 , and power of $80 \%$. Written informed consent was obtained from all participants for inclusion before they participated. This study was conducted in accordance with the Declaration of Helsinki, and the protocol was approved by Universiti Kebangsaan Malaysia's Ethics Committee (JEP-2019-012).

Refractive errors for all participants were measured using a Topcon RM-8800 autorefractometer, followed by subjective refraction. Corneal curvature and asphericity were measured using a Medmont-E300 topographer, and subsequent data analysis was conducted using the Medmont Studio 4 v4.11.1.1. The flat and steep $\mathrm{K}$ measurements were summed and divided by two to represent the mean corneal curvature. Corneal 
asphericity Q was calculated based on eccentricity $e$ values using the formula (Horner et al. 2000).

$$
Q=-e^{2}
$$

Central corneal thickness, anterior chamber depth, vitreous chamber depth, and axial length were measured using an A-scan ultrasound pachymeter and biometer (Tomey AL-2000). Alcaine 0.5\% (proparacaine hydrochloride) was administered before the measurement of these parameters using a sterilized probe. For central corneal thickness measurement, the speed was set at $1,640 \mathrm{~m} / \mathrm{s}$ (Kramme et al. 2011). The probe was placed at a right angle on the central cornea, where the mean of three measurements was taken as the central corneal thickness. The mean of five measurements was taken for the measurements of the other parameters. Measurements with the Medmont topographer were always done before using probes on the surface of the cornea.

\section{RESULTS}

The means and standard deviations for ocular biometry measurements for each experimental group (Table 1). One-way ANOVA showed that there was a statistically significant difference between emmetropic, low myopic, and high myopic groups in axial length $(\mathrm{F}(2,127)=$ 95.49, $\mathrm{p}<0.001)$, anterior chamber depth $(\mathrm{F}(2,127)=$ $10.42, \mathrm{p}<0.001)$ and vitreous chamber depth $(\mathrm{F}(2,127)$ $=74.08, \mathrm{p}<0.001)$.

TABLE 1. Mean and standard deviation for each ocular parameter for emmetropia, low myopia, and high myopia. SE = spherical equivalent. Differences in means between groups were analyzed using one-way ANOVA

\begin{tabular}{|c|c|c|c|c|}
\hline \multirow[b]{2}{*}{ Ocular parameters } & \multicolumn{3}{|c|}{ Mean \pm standard deviation $(\mathrm{n}=127)$} & \multirow[b]{2}{*}{ p-value } \\
\hline & $\begin{array}{c}\text { Emmetropia } \\
\quad \mathrm{n}=31 \\
(\mathrm{SE}= \pm 0.50 \mathrm{D})\end{array}$ & $\begin{array}{c}\text { Low myopia } \\
n=72 \\
(-0.75 \mathrm{D} \leq \mathrm{SE}<-6.00 \mathrm{D})\end{array}$ & $\begin{array}{l}\text { High myopia } \\
\quad \mathrm{n}=24 \\
(\mathrm{SE} \geq-6.00 \mathrm{D})\end{array}$ & \\
\hline Axial length (mm) & $22.97 \pm 0.13$ & $24.15 \pm 0.87$ & $26.13 \pm 0.90$ & $p<0.001$ \\
\hline $\begin{array}{l}\text { Anterior chamber } \\
\text { depth }(\mathrm{mm})\end{array}$ & $3.25 \pm 0.31$ & $3.41 \pm 0.31$ & $3.61 \pm 0.20$ & $p<0.001$ \\
\hline $\begin{array}{l}\text { Central corneal } \\
\text { thickness }(\mu \mathrm{m})\end{array}$ & $545.74 \pm 34.70$ & $549.28 \pm 33.10$ & $545.81 \pm 33.76$ & $p=0.84$ \\
\hline $\begin{array}{l}\text { Vitreous chamber } \\
\text { depth }(\mathrm{mm})\end{array}$ & $15.59 \pm 0.74$ & $16.62 \pm 0.86$ & $18.34 \pm 0.94$ & $p<0.001$ \\
\hline $\begin{array}{l}\text { Central corneal } \\
\text { curvature }(\mathrm{mm})\end{array}$ & $7.67 \pm 0.27$ & $7.67 \pm 0.24$ & $7.68 \pm 0.27$ & $p=0.97$ \\
\hline $\begin{array}{l}\text { Corneal asphericity } \\
\text { Q }\end{array}$ & $-0.28 \pm 0.12$ & $-0.29 \pm 0.11$ & $-0.30 \pm 0.13$ & $p=0.90$ \\
\hline
\end{tabular}

There is a highly significant, strong negative correlation between axial length and spherical equivalent $(\mathrm{SE})(\mathrm{r}(127)=-0.84, \mathrm{p}<0.001)$ (Figure 1) and between vitreous chamber depth and SE $(\mathrm{r}(127)=$ $-0.81, \mathrm{p}<0.001)$ (Figure 2). The correlation between anterior chamber depth and SE is small but statistically significant $(\mathrm{r}(127)=-0.36, \mathrm{p}<0.001)$ (Figure 3). There is no significant correlation between SE and central corneal thickness $(\mathrm{r}(127)=-0.001, \mathrm{p}=0.99)$ and corneal curvature $(\mathrm{r}(127)=0.10, \mathrm{p}=0.91)$. 


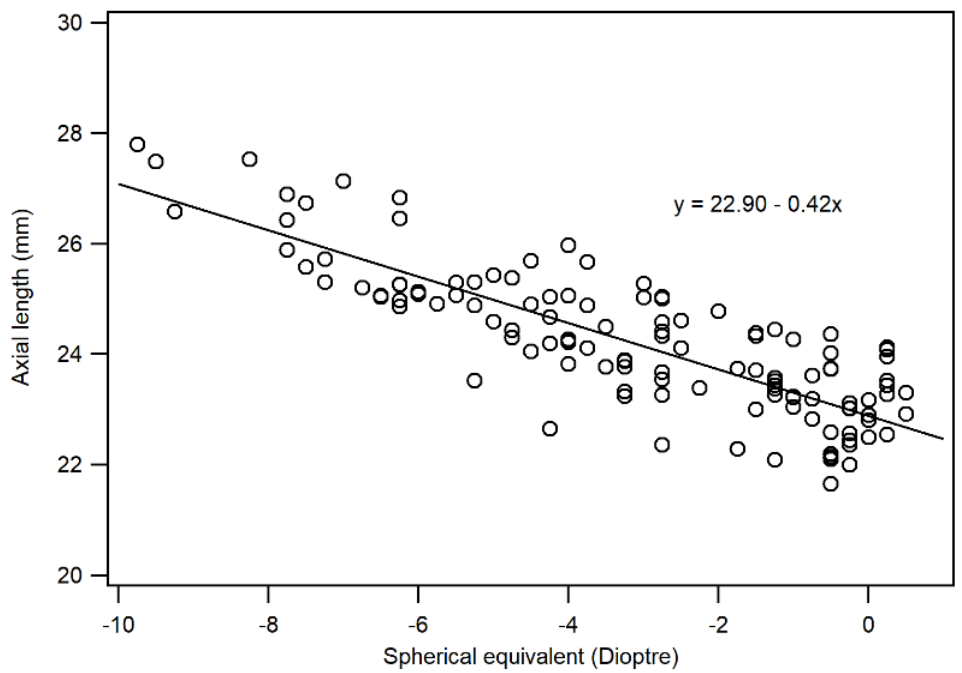

FIGURE 1. Axial length (mm) plotted as a function of spherical equivalent. A regression function is used to fit the data, and the regression equation is shown

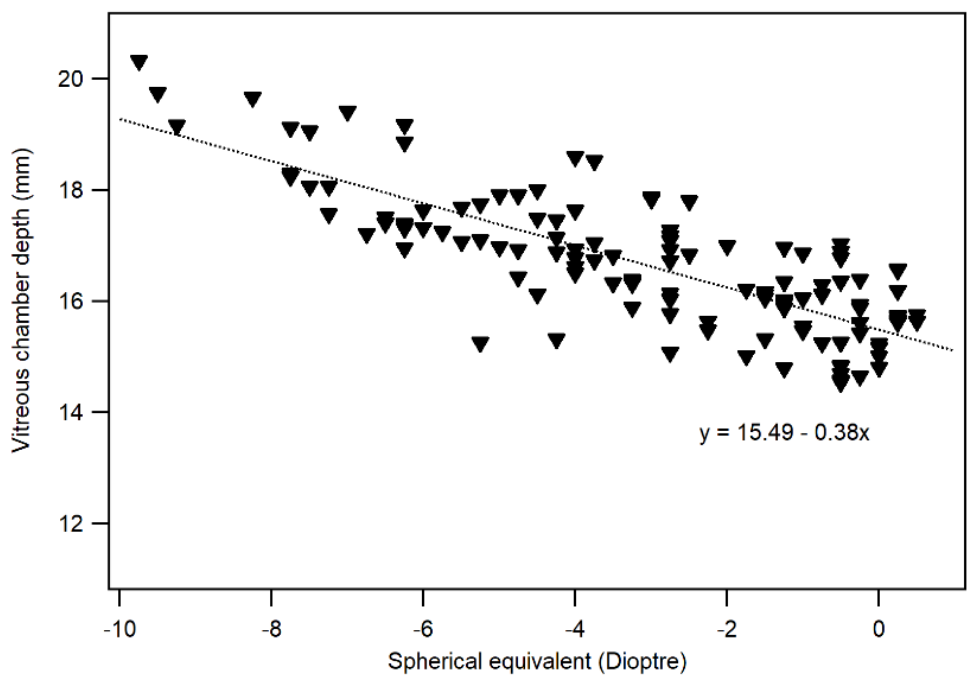

FIGURE 2. Vitreous chamber depth ( $\mathrm{mm}$ ) plotted as a function of spherical equivalent. A regression function is used to fit the data, and the regression equation is shown

There is no statistical significance between the groups in central corneal thickness $(\mathrm{F}(2,127)=0.17, \mathrm{p}=$ $0.84)$ and corneal curvature $(\mathrm{F}(2,127)=0.31, \mathrm{p}=0.97)$. There is a tendency for corneal asphericity $\mathrm{Q}$ to be more negative (i.e. cornea becomes more prolate) in the high myopia group however it is not statistically significant $(\mathrm{F}(2,127)=0.11, \mathrm{p}=0.90)$.
Figure 4(a) shows the correlation between central corneal curvature and spherical equivalent is not statistically significant $(\mathrm{r}(127)=-0.10, \mathrm{p}=0.91)$. However, when central corneal curvature is plotted against axial length (Figure 4(b)) there is a positive and highly significant correlation between these two parameters $(\mathrm{r}(127)=$ $0.30, \mathrm{p}=0.001)$. 


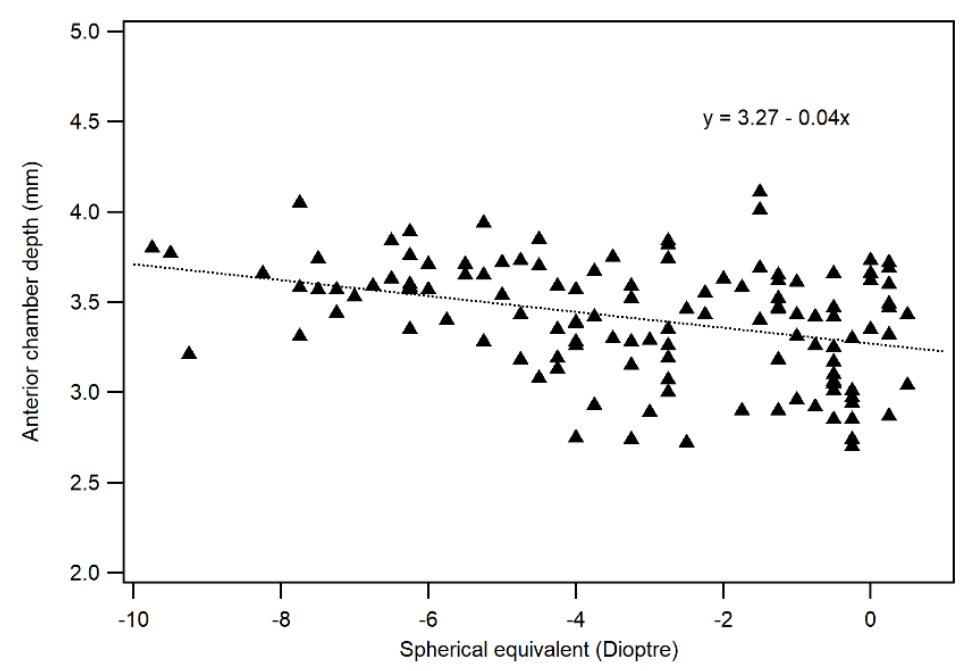

FIGURE 3. Anterior chamber depth ( $\mathrm{mm}$ ) plotted as a function of spherical equivalent. A regression function is used to fit the data, and the regression equation is shown
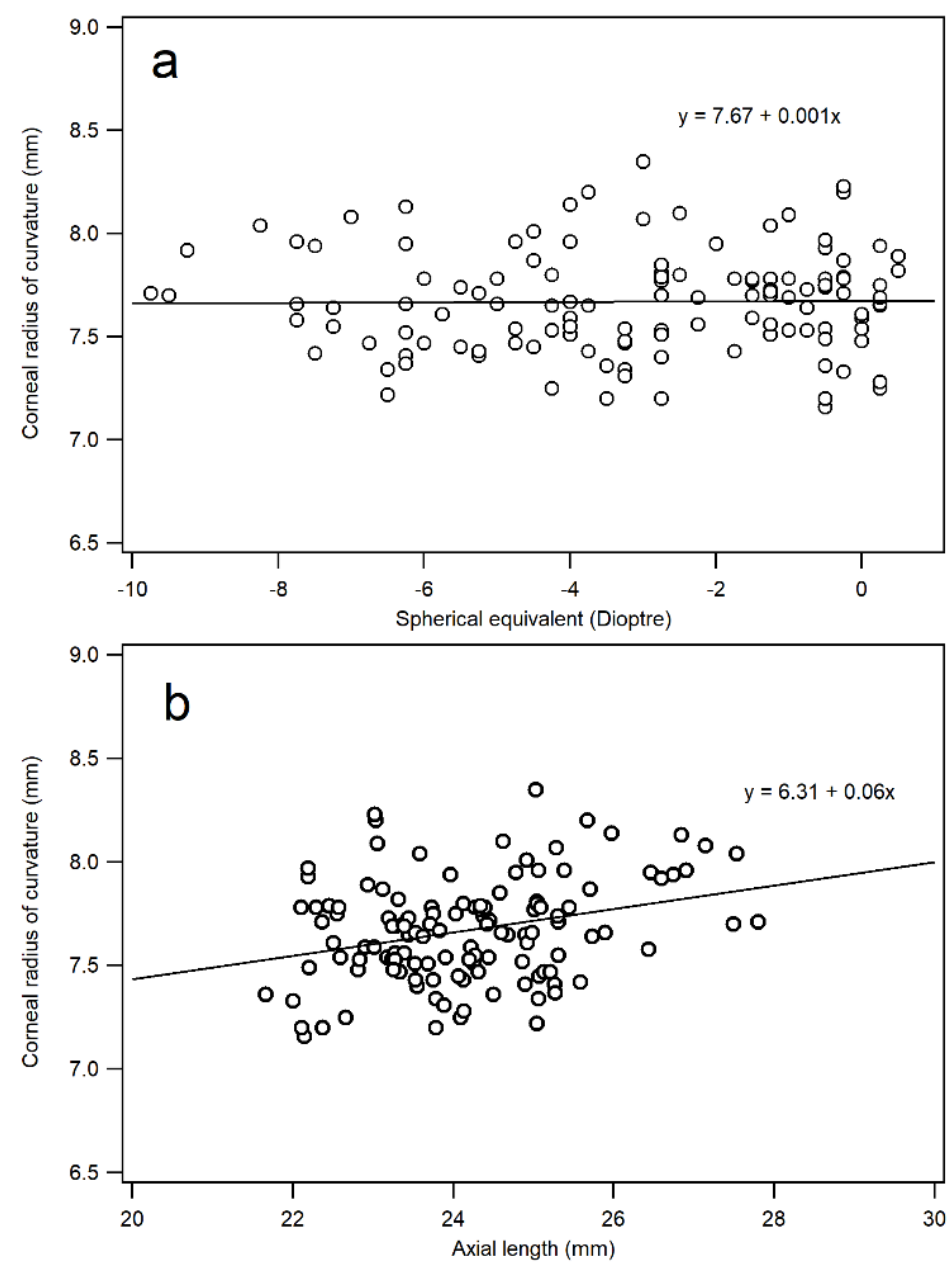

FIGURE 4. Central corneal curvature plotted against myopic spherical equivalent (a) and axial length (b). A regression function is used to fit the data, and the equation is given for each panel 


\section{DISCUSSION}

The increase in axial length is accompanied by an increase in myopia's magnitude that we reported are in agreement with those reported previously for similar population samples (Blanco et al. 2008; Grosvenor \& Scott 1994; Lin et al. 1996). Numerous studies have reported that an increase in axial length is one of the main predictors of an increase in myopia level (Lim et al. 2010)

Inconsistent findings in the change of specific corneal parameters as myopia's magnitude increases may be due to myopia's categorization. As myopia increases in magnitude, central corneal thickness has been reported to be either unchanged (Al-Mezaine et al. 2009; Mostafa et al. 2018), thicker (Wang et al. 2015), or thinner (Chang et al. 2001). Thicker corneas in high myopes have been attributed to differences in tear film thickness (Wang et al. 2015). However, we found that the central corneal thickness between the emmetropic and the myopic groups was not significantly different. The correlation between spherical equivalent and central corneal thickness was also not statistically significant. It has been reported that the cornea becomes thinner with increasing age (Kadhim \& Farhood 2016) where an increase in age by ten years decreases central corneal thickness by $7 \mu \mathrm{m}$ (Iyamu $\&$ Osuobeni 2012). In this study, our participants' age range is between 21 and 35 years old, which could explain why there was no significant difference in corneal thickness between our emmetropia, low myopia, and high myopia groups.

We did not find significant differences in corneal asphericity (Q) between the emmetrope and myope groups, and there was no significant correlation between $\mathrm{Q}$ and participants' spherical equivalent. Other studies have reported similar results (Budak et al. 1999; Rowsey et al. 1991). However, a study reported that Q was significantly different in four subgroups of myopia where the authors also included those with astigmatism magnitude higher than -1.00DC (Hashemi et al. 2013). Our participants, however, only had low astigmatism, which could explain the differences in our findings. There are conflicting results on how Q changes with increasing myopia. The cornea was reported to be more prolate $(\mathrm{Q}$ value becomes more positive) (Zhang et al. 2011) or more oblate (Horner et al. 2000) as myopia increases. These differences have been attributed to differences in the studied populations' ethnicity (Fuller \& Alperin 2013; Zhang et al. 2011) and whether measurements are made cross-sectionally (Zhang et al. 2011) or longitudinally (Horner et al. 2000). Our study did not specifically compare $\mathrm{Q}$ between different ethnicities, and measurements of $\mathrm{Q}$ were made cross-sectionally, which could explain why our findings were different from those studies described above.

We also found that the corneal radius of curvature was not significantly different between our participant groups (Table 1), and it did not correlate significantly with the magnitude of myopia (Figure 4(a)). Previous studies have reported similar results (Chang et al. 2001; MohdAli et al. 2009; Okukpon \& Ojo 2018; Wang et al. 2015). Indeed, it was found that myopes have steeper cornea than hyperopes but essentially similar to emmetropes (Hashemi et al. 2013). Although cornea radius of curvature did not correlate significantly with myopia spherical equivalent, we found that corneal curvature correlates positively with axial length (Figure 4(b)), in agreement with an earlier study (Chang et al. 2001). Our results suggest that axial length, rather than spherical equivalent, is a more sensitive measure to determine the change in corneal radius of curvature for myopic patients. Indeed, as the eye elongates, the cornea compensates by being flatter as a measure to maintain an emmetropic condition (Scheiman et al. 2016), but the flattening of the cornea was not enough to counter the increase in axial length, resulting in an overall myopic refractive state.

\section{CONCLUSION}

As the eye becomes more myopic, axial length increases where it is contributed mainly by the increase in vitreous chamber depth and, to a lesser extent, anterior chamber depth. The axial length, rather than categorizing myopia by spherical equivalent, correlates with corneal curvature in myopic participants. Axial length must be carefully considered when the cornea is involved in medical or surgical intervention, such as orthokeratology and refractive surgery. The associations between corneal curvature and asphericity with the degree of myopia deserve further study.

\section{ACKNOWLEDGEMENTS}

We acknowledge the Optometry \& Vision Science Program, Universiti Kebangsaan Malaysia (UKM) for instruments and facility support; Professor Dr. Sharanjeet Kaur, Professor Dr. Kamaruzaman Jusoff, and Professor Dr. Wan Zurinah Wan Ngah for insights and comments during the preparation of this manuscript. Special thanks to the Deputy Dean's Office (Research and Innovation) and Centre for Community Health Studies, Faculty of Health Sciences, UKM for administrative support. The authors declare no conflict of interest. This research received no external funding. 


\section{REFERENCES}

Al-Mezaine, H.S., Al-Obeidan, S., Kangave, D., Sadaawy, A., Wehaib, T.A. \& Al-Amro, S.A. 2009. The relationship between central corneal thickness and degree of myopia among Saudi adults. International Ophthalmology 29: 373378. doi:10.1007/s10792-008-9249-8.

Atchison, D.A., Jones, C.E., Schmid, K.L., Pritchard, N., Pope, J.M., Strugnell, W.E. \& Riley, R.A. 2004. Eye shape in emmetropia and myopia. Investigative Ophthalmology \& Visual Science 45(10): 3380-3386.

Blanco, F.G., Fernandez, J.C.S. \& Sanz, M.A.M. 2008. Axial length, corneal radius, and age of myopia onset. Optometry and Vision Science 85: 89-96.

Budak, K., Khater, T.T., Friedman, N.J., Holladay, J.T. \& Koch, D.D. 1999. Evaluation of relationships among refractive and topographic parameters. Journal of Cataract \& Refractive Surgery 25: 814-820.

Chang, S., Tsai, I., Hu, F., Lin, L.L. \& Shih, Y.F. 2001. The cornea in young myopic adults. British Journal of Ophthalmology 85(8): 916-920. doi:10.1136/bjo.85.8.916.

Chen, M.J., Liu, Y.T., Tsai, C.C., Chen, Y.C., Chou, C.K. \& Lee, S.M. 2009. Relationship between central corneal thickness, refractive error, corneal curvature, anterior chamber depth and axial length. Journal of the Chinese Medical Association 72: 133-137.

Cho, P. \& Lam, C. 1999. Factors affecting the central corneal thickness of Hong Kong-Chinese. Current Eye Research 18(5): 368-374.

Dogan, M., Elgin, U., Sen, E., Tekin, K. \& Yilmazbas, P. 2017. Comparison of anterior segment parameters and axial lengths of myopic, emmetropic, and hyperopic children. International Ophthalmology 39: 335-340. doi:10.1007/ s10792-017-0816-8.

Flitcroft, D.I., He, M., Jonas, J.B., Jong, M., Naidoo, K., OhnoMatsui, K., Rahi, J., Resnikoff, S., Vitale, S. \& Yannuzzi, L. 2019. IMI - Defining and classifying myopia: A proposed set of standards for clinical and epidemiologic studies. Investigative Ophthalmology and Visual Science 60(3): M20-M30. doi:10.1167/iovs.18-25957.

Fuller, D.G. \& Alperin, D. 2013. Variations in corneal asphericity (Q value) between African-Americans and whites. Optometry and Vision Science 90(7): 667-673.

Grosvenor, T. \& Scott, R. 1994. Role of the axial length/corneal radius ratio in determining the refractive state of the eye. Optometry and Vision Science: Official Publication of the American Academy of Optometry 71(9): 573-579.

Guan, H., Wang, H., Du, K., Zhao, J., Boswell, M., Shi, Y. \& Qian, Y. 2018. The effect of providing free eyeglasses on children's mental health outcomes in China: A cluster-randomized controlled trial. International Journal of Environmental Research and Public Health 15(12): 2749.

Hashemi, M., Falavarjani, K.G., Aghai, G.H., Aghdam, K.A. \& Gordiz, A. 2013. Anterior segment study with the pentacam scheimpflug camera in refractive surgery candidates. Middle East African Journal of Ophthalmology 20: 212. doi:10.4103/0974-9233.114793.
Hashmani, N., Hashmani, S., Hanfi, A.N., Ayub, M., Saad, C.M., Rajani, H., Muhammad, M.G. \& Aziz, M. 2017. Effect of age, sex, and refractive errors on central corneal thickness measured by Oculus Pentacam ${ }^{\circledR}$. Clinical Ophthalmology 11: 1233-1238. doi:10.2147/OPTH.S141313.

Horner, D.G., Soni, P.S., Vyas, N. \& Himebaugh, N.L. 2000. Longitudinal changes in corneal asphericity in myopia. Optometry and Vision Science 77: 198-203.

Hosseini, S.M.A., Mohidin, N., Abolbashari, F., Mohd-Ali, B. \& Santhirathelagan, C.T. 2013. Corneal thickness and volume in subclinical and clinical keratoconus. International Ophthalmology 33(2): 139-145.

Iyamu, E. \& Osuobeni, E. 2012. Age, gender, corneal diameter, corneal curvature and central corneal thickness in Nigerians with normal intra ocular pressure. Journal of Optometry 5: 87-97. doi:10.1016/j.optom.2012.02.001.

Kadhim, Y.J. \& Farhood, Q.K. 2016. Central corneal thickness of Iraqi population in relation to age, gender, refractive errors, and corneal curvature: A hospital-based cross-sectional study. Clinical Ophthalmology 10: 2369-2376. doi:10.2147/OPTH. S116743.

Kramme, R., Hoffmann, K.P. \& Pozos, R.S. 2011. Springer Handbook of Medical Technology. Springer-Verlag Berlin Heidelberg.

Lim, L.S., Saw, S.M., Jeganathan, V.S.E., Tay, W.T., Aung, T., Tong, L., Mitchell, P., Wong, T.Y. 2010. Distribution and determinants of ocular biometric parameters in an Asian population: The Singapore Malay eye study. Investigative Ophthalmology \& Visual Science 51(1): 103-109.

Lin, L.L., Shih, Y.F., Lee, Y.C., Hung, P.T. \& Hou, P.K. 1996. Changes in ocular refraction and its components among medical students--a 5-year longitudinal study. Optometry and Vision Science: Official Publication of the American Academy of Optometry 73(7): 495-498.

Liong, S.L., Mohidin, N., Tan, B.W. \& Ali, B.M. 2015. Refractive error, visual acuity, and corneal-curvature changes in high and low myopes with orthokeratology treatment: A Malaysian study. Taiwan Journal of Ophthalmology 5(4): 164-168.

Mohan, S., Aggarwal, A., Dada, T., Vanathi, M. \& Panda, A. 2007. Pachymetry: A review. DOS Times 12: 19-28.

Mohd-Ali, B., Ching, H.O. \& Abd-Latif, N.A. 2009. Corneal thickness and curvature of one sample of young myopic population in Malaysia. Jurnal Sains Kesihatan Malaysia 7: 49-58.

Mohidin, N., Hoon, N.L., Ishak, B. \& Mohd-Ali, B. 2014. Cornea endothelial cell morphology in short-term silicone hydrogel soft contact lens wearers-asian context. International Journal of Collaborative Research on Internal Medicine \& Public Health 6(12): 296.

Mostafa, A., Mohamed, M. \& Mohamed, M. 2018. Correlation between central corneal thickness and degree of myopia. The Egyptian Journal of Hospital Medicine 70: 109-113. doi:10.12816/0042971.

Okukpon, J.O. \& Ojo, O.M. 2018. Corneal curvature in young high myopic undergraduates in southern Nigeria. International Journal of Research in Medical Sciences 6: 2592. doi:10.18203/2320-6012.ijrms20182975. 
Rowsey, J.J., Waring, G.O., Monlux, R.D., Balyeat, H.D., Stevens, S.X., Culbertson, W., Barron, B., Nelson, D., Asbell, P., Smith, R., Arentsen, J., Cowden, J. \& Lynn, M.J. 1991. Corneal topography as a predictor of refractive change in the prospective evaluation of radial keratotomy (PERK) study. Ophthalmic Surgery, Lasers and Imaging Retina 22: 370-380.

Saw, S.M., Gazzard, G., Shih-Yen, E.C. \& Chua, W.H. 2005. Myopia and associated pathological complications. Ophthalmic and Physiological Optics 25(5): 381-391.

Scheiman, M., Gwiazda, J., Zhang, Q., Deng, L., Fern, K., Manny, R.E., Weissberg, E., Hyman, L. \& COMET Group. 2016. Longitudinal changes in corneal curvature and its relationship to axial length in the correction of myopia evaluation trial (COMET) cohort. Journal of Optometry 9(1): 13-21.

Stone, R. \& Flitcroft, D. 2004. Ocular shape and myopia. Annalsacademy of Medicine Singapore 33(1): 7-15.

Teoh, L.S., Foo, S.W., Mansurali, V.N., Ang, E.L., Md Noh, U.K. \& Bastion, M-L.C. 2017. Evaluation of corneal endothelial cell loss after uncomplicated phacoemulsification cataract surgery with intracameral phenylephrine. The Asia-Pacific Journal of Ophthalmology 6(4): 318-325.
Turner, E.L., Dobson, J.E. \& Pocock, S.J. 2010. Categorisation of continuous risk factors in epidemiological publications: A survey of current practice. Epidemiologic Perspectives \& Innovations 7(1): 1-10.

Wang, X., Dong, J. \& Wu, Q. 2015. Corneal thickness, epithelial thickness and axial length differences in normal and high myopia. BMC Ophthalmology 15: 1-5. doi:10.1186/s12886015-0039-6.

Zhang, Z., Wang, J., Niu, W., Ma, M., Jiang, K., Zhu, P. \& Ke, B. 2011. Corneal asphericity and its related factors in 1052 Chinese subjects. Optometry and Vision Science 88(10): 1232-1239.

Centre for Community Health Studies

Faculty of Health Sciences

Universiti Kebangsaan Malaysia

Jalan Raja Muda Abdul Aziz

50300 Kuala Lumpur, Federal Territory

Malaysia

*Corresponding author; email: izzuddin.hairol@ukm.edu.my

Received: 8 December 2019

Accepted: 3 February 2021 